\title{
EFFECT OF PROCESS PARAMETERS ON THE MECHANICAL PROPERTIES AND FAILURE BEHAVIOR OF SPOT WELDED LOW CARBON STEEL
}

\author{
Farizah Adliza Ghazali ${ }^{1,2 *}$, Yupiter H.P. Manurung ${ }^{1}$, Mohamed Ackiel \\ Mohamed $^{2}$,Siti Khadijah Alias ${ }^{1}$, Shahrum Abdullah ${ }^{3}$ \\ ${ }^{\mathbf{1}}$ Faculty of Mechanical Engineering, Universiti Teknologi Mara \\ 40200Shah Alam, Selangor, Malaysia \\ ${ }^{2}$ Fabrication and Joining, Universiti Kuala Lumpur - Malaysia France Institute \\ 43650 Bandar BaruBangi, Selangor, Malaysia \\ ${ }^{3}$ Dept. of Mechanical and Materials Engineering \\ Universiti Kebangsaan Malaysia, \\ 43600 UKM Bangi, Selangor \\ *Email: farizahadliza@ unikl.edu.my \\ Phone : +6038913280; Fax : +60389222734
}

\begin{abstract}
In this research, the effect of spot welding parameters on weld quality was investigated. The main affecting welding parameters such as weld current, weld time, electrode force and holding time were determined as the basis for quality evaluation. The selected quality features were classified into mechanical properties and failure behavior, which were required for application with highly dynamic loading. The peak load as one of the important mechanical properties, as well as the two distinct failure modes which were cross-nugget and complete button pull, were observed using tensile-shear stress. To obtain detailed shear stress testing results and to determine the significance of parameters, a servo-hydraulic testing machine was run at a constant cross-head speed of $2 \mathrm{~mm} / \mathrm{min}$ followed by statistical analysis methods, which were Taguchi's $\mathrm{L}_{16}$ orthogonal array and Analysis of Variance (ANOVA). Furthermore, the failure mode was to be observed based on the fracture surface used as reference for acceptance or rejection of the weld joint. Based on the results, the weld current was the significant factor affecting shear stress and the complete button pull was mostly found, which leads to the satisfactory condition of the joint. Cross-nugget and full button pull-out were the dominant failures observed in the lap-shear test. The cross-nugget failure leads to a low shear load, while complete button pull-out displays maximum shear load.
\end{abstract}

Keywords: Resistance spot welding; process parameter; shear load; failure mode

\section{INTRODUCTION}

Resistance spot welding (RSW) is widely used for producing a typical vehicle body-inwhite (BIW), normally made of thin metal sheets that are connected together by clamping the sheets with two pincers while applying force and transmitting current; eventually a nugget develops and the interface locally disappears. Usually indexes for the quality aspect of resistance spot welds will consist of fusion zone size, weld mechanical performance and failure modes. The important changes occur in the mechanical and metallurgical properties of the spot welds area during the spot weld 
process $[1,2]$. The investigation of this change is most important for the safety and quality of the welded joints [3, 4]. Welding time, welding current and load applied on the electrode prior to transmitting the welding current exhibit important effects on mechanical properties due to their influence on current flow [5]. An increase in weld current and heat input increased the failure load of spot welds on carbon and stainless steels, aluminum and magnesium alloys [3, 6-8]. The shear strength of a single lap spot welded joint is a complex phenomenon, which depends on several factors, namely, welding parameters and base metal properties $[9,10]$. The main failure modes for static weld strength using lap-shear are cross-nugget and complete button pull-out failure [8, 11]. In the cross-nugget failure mode, failure occurs via crack propagation through the nugget fusion zone (FZ), while in complete button pull-out mode, the failure occurs via complete nugget withdrawal from one sheet. Welds that fail in complete button pull-out mode provide higher peak loads and energy absorption levels than those which fail in cross-nugget failure mode, thus process parameters should be adjusted so that pull-out failure mode is guaranteed $[12,13]$.

A common problem that has faced the manufacturer is the control of the input process parameters to obtain good welded joint quality. Traditionally, it has been necessary to determine the weld parameter input for every new welded product to obtain a welded joint with the required specification through a time-consuming trial and error development effort, with weld input parameters chosen by the skill of the machine operator. In order to overcome this problem, various optimization methods can be applied to define the desired output variables through developing mathematical models to specify the relationship between the input parameters and the output variables. In the last few decades, design of experiment (DoE) techniques have been used to determine such relationship and optimization. One single typical automotive car body contains about 300 sheet metal parts, joined by about a thousand spot welds [14]. For this reason, the quality, performance and failure characteristics of resistance spot welds are important to be evaluated for determining the durability and the safe design of the vehicles, as they transfer load through the structure during dynamical load and crash $[15,16]$. The aim of the present study is therefore to investigate the effect of process parameter optimization on the shear load and failure mode of resistance spot welded low carbon steel (LcS).

\section{EXPERIMENTAL DESIGN AND PROCEDURES}

The base metal used in this investigation was low carbon steel $(\mathrm{LcS})$ sheets with $1.2 \mathrm{~mm}$ thickness. The mechanical properties of the base metals were determined using a spark emission machine and using a standard tensile test in accordance with ASTM E8M [17]. The chemical composition and mechanical properties of this steel are listed in Table 1.

Table 1. Chemical composition and mechanical properties.

\begin{tabular}{cccccccc}
\hline $\mathrm{C}$ & $\mathrm{Si}$ & $\mathrm{Mn}$ & $\mathrm{P}$ & $\mathrm{S}$ & $\mathrm{Fe}$ & $\begin{array}{c}\text { Modulus of } \\
\text { elasticity [18] }\end{array}$ & $\begin{array}{c}\text { Tensile strength } \\
(\mathrm{MPa})\end{array}$ \\
\hline 0.05 & 0.01 & 0.21 & 0.011 & 0.005 & Bal. & 206 & 307 \\
\hline
\end{tabular}

The spot welding was carried out using a constant alternating current resistance weld machine (JPC 75-kVA), with an electrode pressing mechanism controlled by a pneumatic application mechanism. The electrode diameter was checked before the start 
of each welding operation. The electrode was ground, cleaned of scales, and measured to ensure that it had the desired diameter before each welding operation. A set of electrodes was kept ready with a similar diameter to that used for welding. A standard size $105 \times 45 \times 1.2 \mathrm{~mm}$ for the base metal was prepared, as shown in Figure 1, and was used to investigate the force of the resistance spot welds under shear loading conditions.

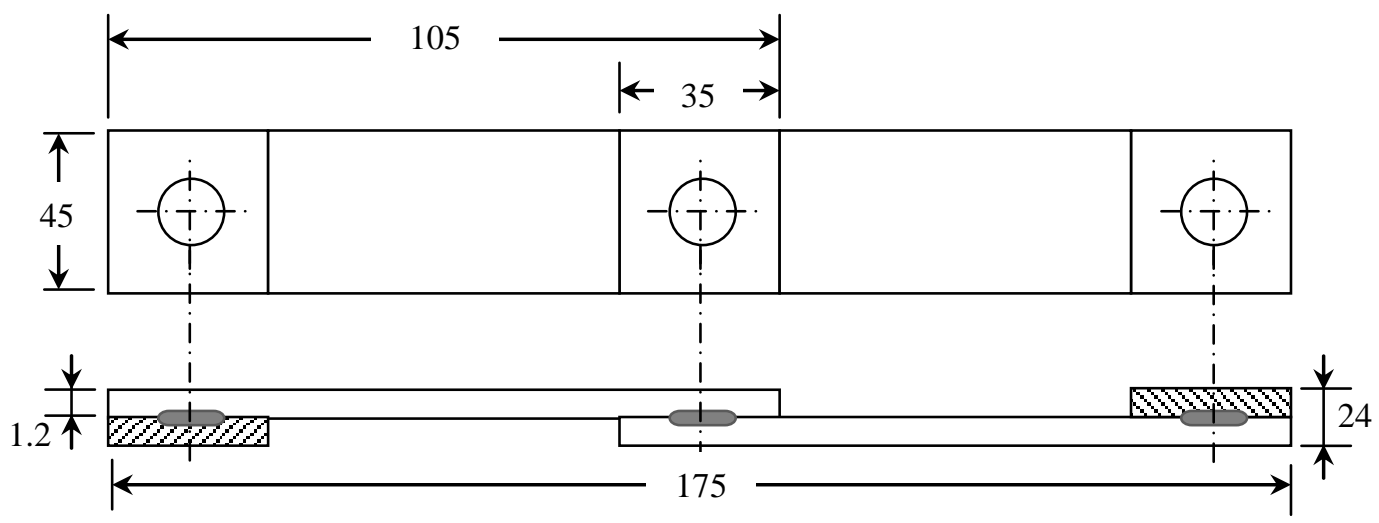

Figure 1. The spot welded experiment sample prepared according to AWS D8.9m [19].

In order to evaluate the mechanical performance and failure mode of the LcS spot welds, the tensile-shear tests were performed at a cross-head of $2 \mathrm{~mm} / \mathrm{min}$ with a $250 \mathrm{kN}$ Instron Universal testing machine. The load was obtained by averaging the strengths of five individual specimens, which were welded with identical welding parameters. Failure modes were determined from the failed samples. From the preliminary experimental results, two levels of welding parameters were selected, as shown in Table 2 . In this study an $\mathrm{L}_{16}$ orthogonal array for the four welding parameters is shown in Table 3.

Table 2. Welding parameters and their levels.

\begin{tabular}{|c|c|c|c|c|}
\hline Symbol & $\begin{array}{l}\text { Welding } \\
\text { parameter }\end{array}$ & Unit & Level 1 & Level 2 \\
\hline$A$ & Weld time & Cycle & 10 & 14 \\
\hline$B$ & Electrode force & $\mathrm{kN}$ & 2.3 & 3.1 \\
\hline C & Weld current & $\mathrm{kA}$ & 8.0 & 10.0 \\
\hline$D$ & Hold time & cycle & 2 & 4 \\
\hline
\end{tabular}

Taguchi's method is a powerful technique for the design of a high quality system. It provides not only an efficient but also a systematic approach to optimize designs for performance and quality. Furthermore, Taguchi parameter design can reduce the fluctuation of system performance and quality to the source of variation. The signalto-noise $(\mathrm{S} / \mathrm{N})$ ratio $(\eta)$ represents the ratio of the mean to the square deviation to measure the quality characteristic deviation from the desired value and can be computed as [20, 21]:

$$
(1 \eta=-10 \log [\mathrm{MSD}]
$$


where MSD is the mean square deviation for the output characteristic and is commonly known as the quality loss function.

Table 3. Experimental layout using an $\mathrm{L}_{16}$ orthogonal array.

\begin{tabular}{ccccc}
\hline Experiment & \multicolumn{4}{c}{ Welding parameter } \\
\cline { 2 - 5 } number & $A$ & $B$ & $C$ & $D$ \\
\hline 1 & 10 & 2.3 & 8 & 2 \\
2 & 10 & 2.3 & 8 & 4 \\
3 & 10 & 2.3 & 10 & 2 \\
4 & 10 & 2.3 & 10 & 4 \\
5 & 10 & 3.1 & 8 & 2 \\
6 & 10 & 3.1 & 8 & 4 \\
7 & 10 & 3.1 & 10 & 2 \\
8 & 10 & 3.1 & 10 & 4 \\
9 & 14 & 2.3 & 8 & 2 \\
10 & 14 & 2.3 & 8 & 4 \\
11 & 14 & 2.3 & 10 & 2 \\
12 & 14 & 2.3 & 10 & 4 \\
13 & 14 & 3.1 & 8 & 2 \\
14 & 14 & 3.1 & 8 & 4 \\
15 & 14 & 3.1 & 10 & 2 \\
16 & 14 & 3.1 & 10 & 4 \\
\hline
\end{tabular}

For the spot weld force, the higher-is-better quality characteristic is occupied [22]. The MSD for the higher-is-better quality is expressed as [23]:

$$
\mathrm{MSD}=\frac{1}{n} \sum_{i=1}^{n} \frac{1}{T_{i}^{2}}
$$

where $n$ is the number of tests and $T_{i}$ is the value of weld force of the $i$ th test.

\section{RESULTS AND DISCUSSION}

\section{Signal-to-noise ratio $(\mathrm{S} / \mathrm{N})$ analysis}

Taguchi recommends analyzing the $\mathrm{S} / \mathrm{N}$ ratio using the conceptual approach that involves graphing the effects and visually identifying the factors that appear to be significant [24]. Table 4 shows the experimental results for the shear load and the corresponding $\mathrm{S} / \mathrm{N}$ ratio which were calculated. The lap-shear tensile test results exhibited that the RSW obtained the maximum shear load of $8.89 \mathrm{kN}$. Figure 2 shows the level effects of each welding parameter. It is clearly observed that the electrode force has the biggest effect on the spot weld $\mathrm{LcS}$. The total mean $\mathrm{S} / \mathrm{N}$ ratio of the experiments was calculated as $18.30 \mathrm{~dB}$, as shown in Figure 2 by a dashed line. The mean $\mathrm{S} / \mathrm{N}$ ratio increases for all welding parameters except holding time. According to the main effect plot, weld time, force and current were at level 2, while for the holding time, there was no major change in the main plot effect. 
Table 4. Experimental results for weld shear load and calculated $\mathrm{S} / \mathrm{N}$ ratios.

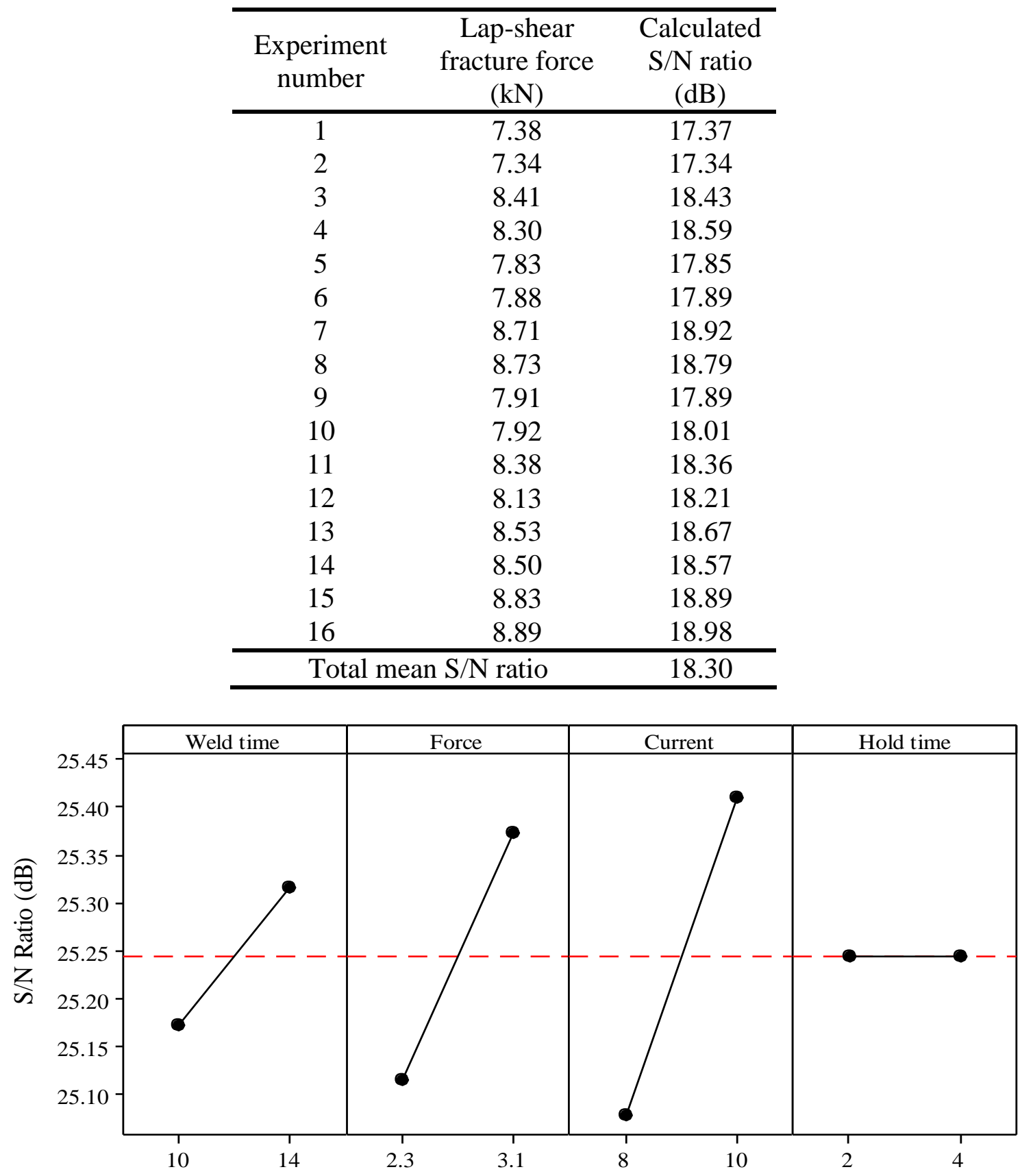

Figure 2. The main effect plot for the $\mathrm{S} / \mathrm{N}$ ratio graph

\section{Analysis of Variance}

The analysis of variance (ANOVA) test was performed to identify the welding parameters that are statistically significant. ANOVA is accomplished by separating the total variability of the $\mathrm{S} / \mathrm{N}$ ratios into contributions by each welding process parameter and the error [25]. It gives clear outlooks as to how far the process parameter influences the response and the level of significance of the factor considered. The percentage of 
contribution of the weld time, electrode force, weld current and hold time are shown in Table 5. The percentage of contribution is a function of the sum of squares for each significant item, which indicates the relative power of a factor to reduce the variation. The associated $p$-value for the model is lower than 0.05 , which indicates that the model is considered to be statistically significant [15]. The high contribution value indicates that the factor is highly significant in affecting the response of the process. In this study, weld current (factor $\mathrm{C}$ ) is a highly significant factor and plays a major role in affecting the shear load of the RSW, as shown in Figure 2 and Table 5, since its p-value is less than 0.05 and the lowest value as compared to electrode force and weld time. The most important factor upon the welding parameters on the shear load is the weld current, which explains $55.73 \%$ contribution of the total variation. The next contribution on shear load comes from the electrode force (factor B) with $33.72 \%$ and the contribution of weld time (factor A) is $10.50 \%$.

Table 5. Results of the analysis of variance (ANOVA) for weld shear load.

\begin{tabular}{clccccc}
\hline Symbol & $\begin{array}{c}\text { Welding } \\
\text { parameters }\end{array}$ & $\begin{array}{c}\text { Degrees } \\
\text { freedom }\end{array}$ & $\begin{array}{c}\text { Sum of } \\
\text { square }\end{array}$ & $F$-ratio & $p$-value & $\begin{array}{c}\text { Contribution } \\
(\%)\end{array}$ \\
\hline$A$ & Weld time & 1 & 0.084062 & 6.00 & 0.032 & 10.50 \\
$B$ & Electrode & 1 & 0.268722 & 19.18 & 0.001 & 33.72 \\
& force & & & & & \\
$C$ & Weld current & 1 & 0.444162 & 31.70 & 0.000 & 55.73 \\
$D$ & Hold time & 1 & 0.000001 & 0.15 & 0.994 & 0.00 \\
Error & & 11 & 0.154140 & - & - & - \\
Total & & 15 & 0.951086 & - & - & 100.00 \\
\hline
\end{tabular}

Table 6. S/N response table for weld shear load.

\begin{tabular}{clccc}
\hline \multirow{2}{*}{ Symbol } & \multirow{3}{*}{ Welding parameter } & \multicolumn{3}{c}{ Mean S/N ratio (dB) } \\
\cline { 3 - 5 } & & Level & Level & \multirow{2}{*}{ Rank } \\
\hline$A$ & Weld time & 25.17 & $25.32^{*}$ & 3 \\
$B$ & Electrode force & 25.11 & $25.37^{*}$ & 2 \\
$C$ & Weld current & 25.08 & $25.41^{*}$ & 1 \\
$D$ & Hold time & $25.24 *$ & 25.24 & 4 \\
\hline
\end{tabular}

*Optimum level

The effect of different welding parameters is shown in Table 6. The optimum levels of different welding parameters for high shear strength obtained are weld time at level 2 (14 cycles), electrode force at level $2(3.1 \mathrm{kN})$, weld current at level $2(10 \mathrm{kA})$ and hold time at level 1 ( 2 cycles).

\section{Failure Mode}

Failure is a competitive phenomenon in which the spot weld failure occurs in a mode of less force. During the tensile-shear test, the stress at the sheet interface and stress created in the nugget circumference were the driving force for the types of failure mode. 
In the RSW, in failure mode it is very important to check for excessive heat and pressure, because excessive heat and pressure can lead to failure mode changes [18]. Suitable welding parameters produce more heat and a nominal weld area, which cause high weld strength. In this section various failure modes which were observed during the quasi-static tensile-shear test of similar RSW between LCS steel sheets are described. Two distinct different failure modes were observed; the partial interfacial and complete button pull-out failure mode (Figure 3). The joint which exhibited a low shear load value failed with a cross-nugget failure mode as shown in Figure 3(a). Therefore, cross-nugget failure occurs easily, leading to a low shear load, as discussed by Khodabakshi et al. [26]. On the other hand, complete pull nugget failure mode was observed in the joint displaying maximum shear load value, as shown in Figure 3(b), which was proposed by the AWS standard and also reported in several other works [5, 27].
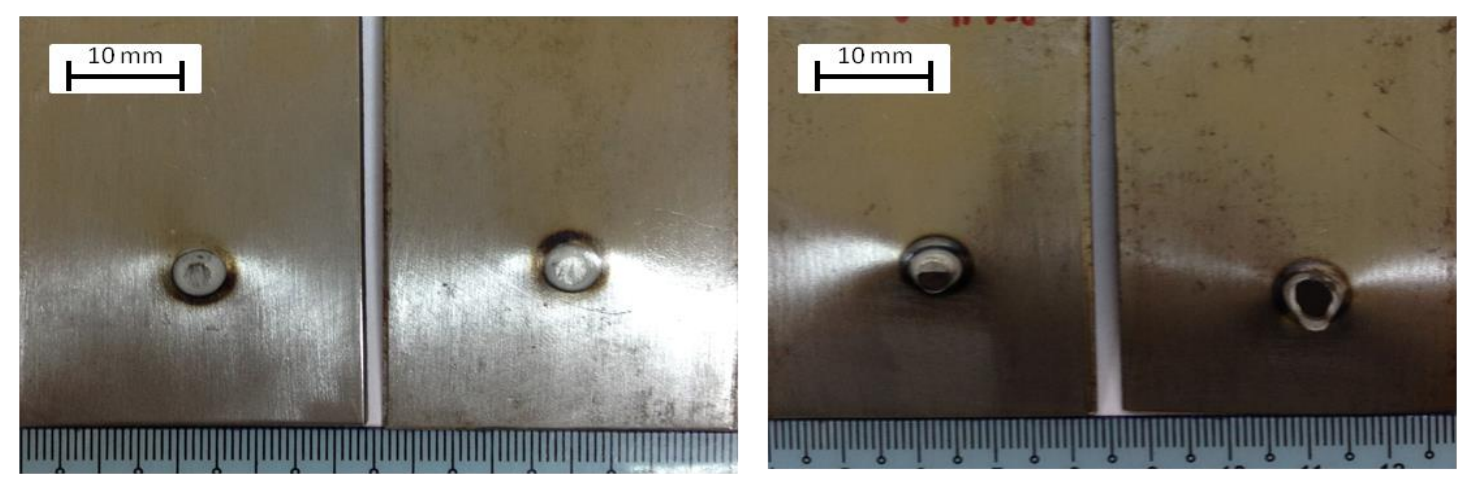

Figure 3. Fracture surfaces of LcS joint after lap-shear tensile tests:

(a) Cross-nugget failure mode and (b) complete button nugget failure mode.

\section{CONCLUSIONS}

Based on the RSW parameters, the tensile-shear load response was studied by using the statistical Taguchi and ANOVA methods. The following results were obtained from the experiment:

(i) The weld current played a vital role and contributed to the overall response, which explains $55.73 \%$ contribution of the total variation. The next contribution on shear load comes from the electrode force with $33.72 \%$ and the contribution of weld time was $10.52 \%$. However, the hold time does not affect the response significantly.

(ii) In lap-shear tensile tests, mainly two different fracture morphologies were observed, which were the cross-nugget failure and full button pull-out failure. The cross-nugget failure occurs easily, leading to a low shear load, while complete pull nugget failure mode was observed in the joint displaying the maximum shear load value. 


\section{ACKNOWLEDGEMENTS}

The authors would like to express their gratitude to Faculty of Mechanical Engineering (UiTM), Advance Manufacturing Technology Excellence Centre (AMTEX) and Universiti Kuala Lumpur-Malaysia France Institute (UniKL-MFI) for the facilities and technical support. The authors also are grateful acknowledge the financial support from UiTM Excellent Funds [600-RMI/DANA 5/3/RIF (320/2012)] for the successful implementation of this project.

\section{REFERENCES}

[1] Charde N. Characterization of spot weld growth on dissimilar joints with different thicknesses. Journal of Mechanical Engineering and Sciences. 2012;2:172-80.

[2] Ishak M, Shah LH, Aisha ISR, Hafizi W, Islam MR. Study of resistance spot welding between aisi 301 stainless steel and AISI 1020 carbon steel dissimilar alloys. Journal of Mechanical Engineering and Sciences. 2014;6:793-806.

[3] Vural MA, Ahmet. On the resistance spot weldability of galvanized interstitial free steel sheets with austenitic stainless steel sheets. Journal of Materials Processing Technology. 2004;153-154:1-6.

[4] Charde N. Microstructure and fatigue properties of dissimilar spot welds joints of AISI 304 and AISI 1008. International Journal of Automotive and Mechanical Engineering. 2013;7:882-99.

[5] Pereira AM, Ferreira JM, Loureiro A, Costa JDM, Bártoloa PJ. Effect of process parameters on the strength of resistance spot welds in 6082-T6 aluminium alloy. Materials and Design. 2010;31:9.

[6] Ozyurek D. An effect of weld current and weld atmosphere on the resistance spot weldability of 304L austenitic stainless steel. Materials and Design. 2008;29:6.

[7] Shamsul JB, Hisyam MM. Study Of Spot Welding Of Austenitic Stainless Steel Type 304. Journal of Applied Sciences Research. 2007;3(11):5.

[8] Goodarzi M, Marashi SPH, Pouranvari M. Dependence of overload performance on weld attributes for resistance spot welded galvanized low carbon steel. Journal of Materials Processing Technology. 2009;209:4379-84.

[9] Bouyousfi B, Sahraoui T, Guessasma S, Chaouch KT. Effect of process parameters on the physical characteristics of spot weld joints. Materials \& Design. 2007;28:5.

[10] Charde N. Effects of electrode deformation of resistance spot welding on 304 austenitic stainless steel weld geometry. Journal of Mechanical Engineering and Sciences. 2012;3:261-70.

[11] Sun X, Stephens EV, Khaleel MA. Effects of fusion zone size and failure mode on peak load and energy absorption of advanced high strength steel spot welds under lap shear loading conditions. engineering Failure Analysis. 2008;15:11.

[12] Marashi P, Pouranvari M, Amirabdollahian S, Abedi A, Goodarzi M. Microstructure and failure behavior of dissimilar resistance spot welds between low carbon galvanized and austenitic stainless steels. Materials Science and Engineering A. 2008;480:5. 
[13] Pouranvari M, Asgari HR, Mosavizadch SM, Marashi PH, Goodarzi M. Effect of weld nugget size on overload failure mode of resistance spot welds. Science and Technology of Welding and Joining. 2007;12:8.

[14] Mali MP, Inamdar KH. Effect of spot weld position variation on quality of automobile sheet metal parts. International Journal of Applied Research in Mechanical Engineering (IJARME). 2012;2.

[15] Pouranvari M, Marashi SPH. Critical review of automotive steels spot welding: process, structure and properties. Science and Technology of Welding and Joining. 2013;18:42.

[16] Pouranvari M, Marashi SPH, Safanama DS. Failure mode transition in AHSS resistance spot welds. Part II: Experimental investigation and model validation. Materials Science and Engineering A. 2011;528:8.

[17] Gerhardt RA. Impedance Spectroscopy and Mobility Spectra. Encyclopedia of Condensed Matter Physics. London: Elsevier; 2005. p. 350-63.

[18] Eitssayeam S, Intatha U, Rujijanagul G, Pengpat K, Tunkasiri T. Structural and electrical properties characterization of $(1-\mathrm{x}) \mathrm{PbZr0}$. 52Ti0. 48O3-xBaFe0. 5Nb0. $5 \mathrm{O} 3$ system. Applied Physics A. 2006;83:295-9.

[19] AWS. Standard test method AWS D8.9M (Recommended Practices for Test Methods for Evaluating the Resistance Spot Welding Behavior of Automotive Sheet Steel Materials). 2012.

[20] Muhammad N, Manurung YH, Hafidzi M, Abas SK, Tham G, Haruman E. Optimzation and modeling of spot welding parameters with simultaneous multiple response consideration using multi-objective Taguchi method and RSM. Journal of Mechanical Engineering and Technology. 2012;26:5.

[21] Muhammad N, Manurung YH, Jaafar R, Abas SK, Tham G, Haruman E. Model development for quality features of resistance spot welding using multiobjective Taguchi method and response surface methodology. Journal of Intelligent Manufacturing 2013;24:8.

[22] Bilici MK. Application of Taguchi approach to optimize friction stir spot welding paramaters of polypropylene. Materials \& Design. 2012;35:6.

[23] Bozkurt Y, Bilici MK. Application of Taguchi approach to optimize of FSSW parameters on joint properties of dissimilar AA2024-T3 and AA5754-H22 aluminium alloys. Materials \& Design. 2013;51:8.

[24] Ghani JA, Choudhury IA, Hassan HH. Application of Taguchi method in the optimization of end milling parameters. Jornal of Materials Processing Technology. 2004;145:8.

[25] Dongxia Y, Xiaoyan L, Dingyong H, Zuoren N, Hui H. Optimization of weld bead geometry in laser welding with filler wire process using Taguchi's approach. Optics and Lasers in Engineering. 2012;44:6.

[26] Khodabakhshi F, Kazeminezhad M, Kokabi AH. Mechanical properties and microstructure of resistance spot welded severely deformed low carbon steel. Materials Science and Engineering: A. 2011;529:237-45.

[27] Afshari D, Sedighi M, Barsoum Z, Peng RL. An approach in prediction of failure in resistance spot welded aluminium 6061-T6 under quasi-static tensile test. Proceedings of the Institution of Mechanical Engineers, Part B: Journal of Engineering Manufacture. 2012. 